\title{
THE ROLE OF SMALL CAVES AS BAT HIBERNACULA IN IOWA
}

\author{
JOSEPH W. DiXON \\ Iowa Grotto of the National Speleological Society, P.O. Box 228, Iowa City, IA 52244, joedixon@mchsi.com
}

\begin{abstract}
Small caves provide habitat for a variety of species, including bats. Past research on cave bats in Iowa has focused on a few large caves. Large caves are uncommon and represent only a portion of the known caves in the state. Since few hibernacula are protected in Iowa and no assessment of small caves has been done, bat census data were compared to cave morphology to determine the significance of small caves as hibernacula. Twelve years of census data (1998-2009) were reviewed for small caves ( $\leq 50.0 \mathrm{~m}$ in length) where hibernating bats had been documented. Four morphological features were compared against the data: entrance aspect, entrance size, cave length, and internal surface area. Student's t-test and Spearman rank correlation were used to test for relationships between the presence and abundance of each species and each of the four morphological features. The eastern pipistrelle occurred in $68 \%$ of the caves, and the little brown bat in $24 \%$. Student's t-test showed a significant correlation with cave length for eastern pipistrelles. Spearman rank correlation showed a significant negative correlation with entrance aspect and significant positive correlations for cave length and internal surface area for eastern pipistrelles. The results are different from previous studies on larger Iowa caves, which showed big brown bats and little brown bats as the most abundant species. Eastern pipistrelles preferred larger caves with vertical entrances. However, large is a subjective term, and the results indicate that small caves are an important source of hibernacula for the eastern pipistrelle.
\end{abstract}

\section{INTRODUCTION}

Small caves often receive little notice from researchers, cavers, and the general public. Larger and more complex caves receive more attention in the form of exploration, study, or recreational caving (Kastning, 2006). This bias is often the result of anthropocentric criteria, such as cave length, which is usually arbitrarily determined (Curl, 1966). For example, among state cave surveys in the Untied States, a minimum length is often established to filter out those caves deemed less important; caves that fall below this discretionary length are simply not included in the survey (Mylroie, 2007). Such discriminatory practices towards small caves are unfortunate, since small caves can occasionally be geologically, historically, or archaeologically significant (Kastning, 2006). In addition, small caves may also be biologically significant, since they have been known to provide habitat for a variety of temperate vertebrate trogloxenic species, such as snakes (Drda, 1968), salamanders (Briggler and Prather, 2006; Camp and Jensen, 2007), and frogs (Blair, 1951; Prather and Briggler, 2001).

The biological significance of small caves may be applicable to bats as well. The fact that larger caves support both greater numbers (Raesley and Gates, 1987; Briggler and Prather, 2003) and greater diversity of bats (Arita, 1996; Fuszara et al., 1996; Brunet and Medellín, 2001; Nui et al., 2007) has been well documented, but small caves have also been observed as a source of hibernacula for some species. For example, Ozark big-eared bats (Corynorhinus townsendii ingens) (Prather and Briggler, 2002) and eastern pipistrelles ${ }^{1}$ (Perimyotis subflavus) (Briggler and Prather, 2003) both utilize small caves as hibernacula. Prather and Briggler (2002) observed that the endangered Ozark big-eared bat used small caves to such an extant that they recommended those in their study area be protected and further surveys for Ozark big-eared bats be conducted in additional small caves.

The lack of interest in small caves could potentially result in the unintentional exclusion of pertinent data. Caves are known to provide some of the most important hibernacula sites for bats (Pierson, 1998), and bat communities in small hibernacula can differ dramatically from those utilizing large hibernacula (Lesiński et al., 2004). Numerous species of cave-hibernating bats exhibit considerable fidelity to hibernacula (Harvey, 1992). For many species of temperate bats, appropriate hibernacula are essential for their survival, and a greater understanding of hibernacula is necessary to make appropriate conservation and management decisions (Brack, 2007).

The state of Iowa has not been an exception to this pattern. Previous research on bats in Iowa caves has been irregular (Bowles et al., 1998) and focused on larger caves, averaging several hundred meters, and occasionally over a thousand meters, in length (see Muir and Polder, 1960; Kunz and Schlitter, 1968; Pruszko and Bowles, 1986; and

\footnotetext{
${ }^{1}$ Editor's Note: The eastern pipistrelle is now more properly called the tri-colored bat. (http://www.batcon.org/news2/scripts/article.asp?articleID=128).
} 
Clark et al., 1987, for names of caves surveyed and Lace and Ohms, 1992; Lace, 1997; Lace and Klausner, 2001; and Lace and Klausner, 2004, for cave lengths). Caves of this size are uncommon and represent only a fraction of the caves found within the state. Of the approximately 1,300 caves documented by the Iowa Grotto of the National Speleological Society (Kambesis and Lace, 2009), it is estimated that as many as $90 \%$ are $50 \mathrm{~m}$ or less in length (Dixon, 2009). Although previous research provided valuable information on the status and distribution of the state's bat populations, these data may not represent a completely accurate assessment because they did not include the typical small caves that dominate Iowa's karst landscape.

Of the eleven species of bats recorded in Iowa (Laubach et al., 1994; Bowles et al., 1998), five have been documented roosting in caves within the state: the big brown bat (Eptesicus fuscus), the eastern pipistrelle, the Indiana bat (Myotis sodalis), the little brown bat (Myotis lucifugus), and the northern myotis (Myotis septentrionalis) (Muir and Polder, 1960; Kunz and Schlitter, 1968; Pruszko and Bowles, 1986; Clark et al., 1987; Iowa Department of Natural Resources, unpublished data; Iowa Grotto, unpublished data). All five are considered regular caveusing species (Harvey, 1992), and of the five, all but the Indiana bat regularly hibernate in caves in eastern Iowa (Laubach et al., 1994). Two of the remaining four species, the little brown bat and the eastern pipistrelle, may even hibernate exclusively in caves in some regions (Tuttle, 2003).

Since the majority of the caves in Iowa are considerably smaller than those that have been surveyed for bats in the past, and few major hibernacula are protected in the state (Bowles et al., 1998), data collected by the Iowa Grotto were examined and compared with attributes of cave morphology using published cave maps to determine what, if any, role small caves played in providing bat hibernacula in Iowa and which of the four commonly occurring cave species utilized these hibernacula on a regular basis. Cave morphology was selected as the limiting factor to be tested, because exterior habitat appears to have little to no relationship with the selection of a cave as a hibernaculum (Raesley and Gates, 1987; Briggler and Prather, 2003), while the interior climate that results from morphological features has been known to influence roost selection (Arita and Vargas, 1995; Rodriquez-Duran, 1998).

\section{Methods}

In 1987, the Iowa Grotto began the Iowa Small Caves Survey Project (ISCSP) with the goal to systematically survey all the caves in the state without bias. In 1998, bat censuses were added as a component of the ISCSP. Surveys were conducted for both summer roosting and hibernating bats using either the direct count or surface area estimate methods as described by Thomas and LaVal (1988). For direct counts, each individual bat was counted and identified to species. For surface area estimates, species were identified, but numbers of bats were estimated. In situations where species identification was not possible (e.g., a high roosting position), only numbers of bats were recorded. All bat censuses were conducted using visual observations only. No bats were handled or molested during sampling procedures.

Twelve years of bat census data collected by the Iowa Grotto were reviewed for caves that met four preestablished criteria: (1) the total surveyed cave length was $50 \mathrm{~m}$ or less, (2) the census date was during hibernation, (3) if bats were present, the direct count method was used, and (4) any observed bats were identified to species. A maximum length of $50 \mathrm{~m}$ was chosen as the limit above which a cave would be considered too large for this study because, as stated previously, many of the historical bat surveys were conducted in caves larger than this and caves longer than $50 \mathrm{~m}$ in length are uncommon in Iowa. Any census conducted during September through mid-May was considered an observation of hibernating individuals. Of the five species of bats that roost in Iowa caves, the eastern pipistrelle is typically the first to enter hibernacula and the last to leave, usually entering in mid-October and departing in mid-April (Schwartz and Schwartz, 2001, p. 80-83). However, they have been known to enter caves for hibernation as early as September and remain as late as mid-May to the end of May (Whitaker and Rissler, 1992; Vincent and Whitaker, 2007). Therefore, the hibernation period for this study was expanded to September through mid-May in order to ensure that early-arriving and latedeparting bats were included in the sample.

Four morphological features were selected for comparison against the bat census data: entrance aspect (compass direction), entrance size, cave length, and internal surface area. Published cave maps (Lace, 1997; Lace and Klausner, 2001; Lace and Klausner, 2004) were used to quantify morphological features. All caves had been surveyed and mapped using standard cartographic techniques described by Dasher (1994). Entrance aspects were measured in degrees of azimuth using a Suunto A1000 compass. The compass was oriented to magnetic north on each map and azimuth bearings were taken on the centerline of the cave entrance that was perpendicular to the plane of the entrance. For caves that had a vertical entrance (i.e., a sinkhole) an aspect of -90 degrees was arbitrarily assigned to represent the nadir since an azimuth bearing did not exist.

Entrance size was determined by measuring the cave entrance at the widest (plan) and highest (profile) points using a Staedtler Engineer's Scale calibrated to the map scale in meters. These values were then used to calculate the approximate size of the entrance in square meters. Cave lengths were taken directly from maps as this feature is a standard component of cave maps published by the Iowa Grotto. Although cave length is a standard for measuring 
cave size, it has been criticized for being potentially inaccurate (Mylroie, 2007). To compensate for this, internal surface area was selected as an alternative means of measuring cave size and was defined as the surface area available for roosting inside each cave and included the walls and ceilings of every surveyed passage. Caves were divided into sections based on profile views. The height, width, and length of each section was then measured using the same Staedtler Engineer's Scale calibrated to the map scale. These values were then used to calculate the surface area in square meters and the results of each section summed to determine the total internal surface area for each cave.

Relationships to cave morphology were determined by comparing the presence and abundance of each species of bat to each of the four morphological features for the caves in which they were documented. Students t-tests were used to test for differences between caves that had a species present versus those that did not for each of aspect, entrance size, length, and internal surface area. Spearman rank correlation $\left(r_{s}\right)$ was used to determine if there were any correlations between each morphological feature and the number of bats from each species. All statistical tests were done at $95 \%$ significance $(P<0.05)$.

\section{RESUlts}

A total of twenty-five caves met the sampling criteria; all caves were solutional caves with a single entrance. Caves were located in seven different counties in northeastern Iowa (Fig. 1). The number of caves per county ranged from 1 to 10 with an average of $3.6( \pm 3.4 \mathrm{SD})$. The average aspect for all caves combined was 97.4 degrees ( \pm 169.8 degrees SD). However, 32\% (8/25) of the caves had a vertical entrance and were therefore assigned a value of -90 degrees since they did not have a geographic aspect. The remaining 17 caves had horizontal entrances. These caves had aspects ranging from 0 to 352 degrees with a mean of 185.5 degrees $( \pm 132.1$ degrees SD). Cave entrances ranged from 0.2 to $27.1 \mathrm{~m}^{2}$ and had a mean of $4.8 \mathrm{~m}^{2}$ ( $\left.\pm 6.4 \mathrm{~m}^{2} \mathrm{SD}\right)$. Cave length ranged from 6.4 to $34.9 \mathrm{~m}$, with an average length of $18.7 \mathrm{~m}( \pm 9.9 \mathrm{~m} \mathrm{SD})$. The internal surface area had a range of 15.5 to $383.8 \mathrm{~m}^{2}$, the mean internal surface area was $125.3 \mathrm{~m}^{2}\left( \pm 103.7 \mathrm{~m}^{2} \mathrm{SD}\right)$.

Three species of bats were documented from 23 of the 25 caves. The eastern pipistrelle was the most common species and was found in $68 \%(17 / 25)$ of the caves. The number of eastern pipistrelles ranged from 0 to 7 with an average of 1.20 ( $\pm 1.47 \mathrm{SD})$ bats per cave. The little brown bat was the second most common species, though it occurred much less frequently than the eastern pipistrelle. Little brown bats were found in only $24 \%(6 / 25)$ of the caves sampled. The number of little brown bats per cave ranged from 0 to 6 with an average of $0.76( \pm 1.67 \mathrm{SD})$. Eastern pipistrelles and little brown bats did not occur together in any of the caves in the sample. Lastly, a single

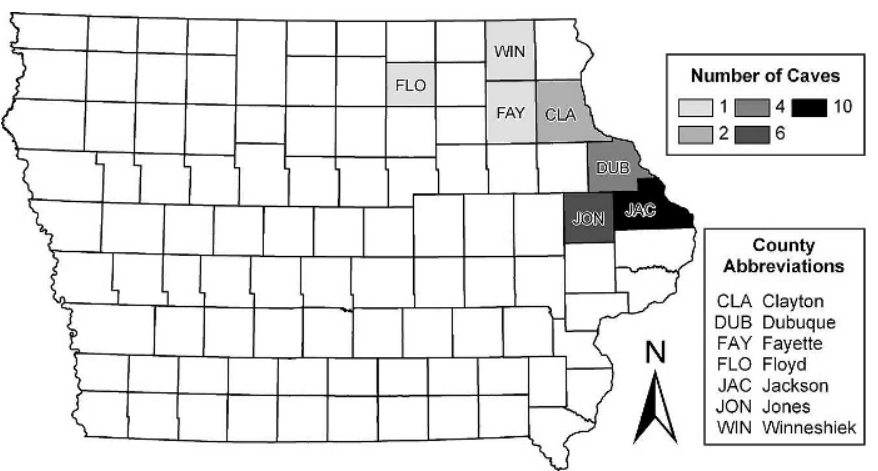

Figure 1. Map of Iowa depicting counties, with numbers of caves included in this study.

big brown bat was found in one cave along with several little brown bats.

The Student's t-test indicated a marginally significant difference for cave length between caves occupied by eastern pipistrelles and those that were unoccupied $(t=$ 2.09, $d f=23, P=0.048)$. The Student's t-tests did not indicate a significant difference for the remaining morphological features, nor did it indicate any significant differences for any of the caves selected by little brown bats (all $P \geq 0.237$ ). Spearman rank correlation indicated that caves selected as hibernacula by eastern pipistrelles had a significant, moderately negative correlation with entrance aspect $\left(r_{s}=-0.408, P=0.043\right)$. There was no discernible relationship between entrance size and hibernacula selection $(P=0.289)$. There was however a very significant, moderate positive correlation for cave length $\left(r_{s}\right.$ $=0.506, P=0.010$ ) and a significant, moderate positive correlation for internal surface area $\left(r_{s}=0.455, P=0.022\right)$ for caves selected by eastern pipistrelles as hibernacula. No significant correlations for little brown bats were detected for any of the four morphological features (all $P \geq 0.388$ ). No statistical analysis was completed for big brown bats since the single individual did not represent a sufficient sample.

\section{Discussion}

With only 25 caves meeting the pre-established criteria, it appears that the criteria were perhaps too restrictive. However, since the focus of this study was on small caves and their use as hibernacula, modifying the criteria to include larger caves or those that contained observations outside of the hibernation period would have invalidated any results. Also, the small percentage of caves without bats is probably the result of sampling error. Some of the surveyed caves were not recorded if bats were not present, according to Ed Klausner (personal communication). An additional limitation would be the failure to include cavelike features or exceptionally small caves. Like other state cave surveys, Iowa utilizes a minimum cave length, in this 
case $15 \mathrm{ft}$ (about $4.5 \mathrm{~m}$ ), and no bat surveys have been undertaken below this limit. The wide range in sampling dates (1998 to 2009) may also introduce temporal variation in distribution and abundance that could potentially bias these results. Due to these limitations, it may be inappropriate to infer that these results are broadly applicable. However, several significant relationships were present and merit discussion.

The results contradict previous surveys that found the big brown bat (Muir and Polder, 1960; Pruszko and Bowles, 1986; Clark et al. 1987) and little brown bat (Iowa Department of Natural Resources, unpublished data) to be the most abundant species in Iowa caves. This is likely due to the history of focusing on large caves within the state. Best et al. (1992) observed that the eastern pipistrelle was the most common species hibernating in small caves $(<$ $65 \mathrm{~m}$ long) surveyed in southern Alabama. Prior to their study, the species was thought to be uncommon in that part of the state. The eastern pipistrelle is not considered uncommon in eastern Iowa (Laubach et al., 1994; Bowles et al., 1998), and these results are supported by Brack et al. (2004), who observed that eastern pipistrelles are usually the only species found in small caves.

Only a single cave harbored more than one species (little brown bats and the single big brown bat). Although caves are known to provide shelter for multiple species (Kunz, 1982), smaller caves and smaller hibernacula, in general, usually have less diverse bat populations (Arita, 1996; Fuszara et al., 1996; Brunet and Medellín, 2001; Lesiński et al., 2004; Nui et al., 2007). The results of this study fit that pattern. The observed segregation of little brown bats and eastern pipistrelles was unexpected, however, since both species are known to hibernate in the same larger caves within Iowa (Laubach et al., 1994). Little brown bats are usually more abundant in large, complex caves (Gates et al., 1984), so the few individuals encountered in these small caves was not surprising. However, there appears to be wide array of morphological features for the surveyed caves that were selected as hibernacula by little brown bats.

Indeed, the caves utilized by little brown bats fell within the range of characteristics of those utilized by eastern pipistrelles and, with the exception of cave length, there was not a significant difference between the caves selected by each species. Due to the small sample size for little brown bats, this segregation may simply be the result of chance. However, it could be the result of previously undocumented interspecific competition, since a smaller cave would be a more limited resource (i.e., less space available for roosting). Previous surveys in the state would not have observed this competition because they were conducted in larger caves. Future research efforts in small caves should include little brown bats to further clarify this behavior.

The low numbers of eastern pipistrelles matched previously documented behavior for this species. Eastern pipistrelles hibernate in small numbers as solitary individuals (Fujita and Kunz, 1984; Vincent and Whitaker, 2007), and their numbers in caves can vary considerably during hibernation (Brack et al., 2003). The lack of a relationship with cave entrance size matched expected behavior as well. As with this study, Briggler and Prather (2003) found no significant relationship with entrance size of caves used by eastern pipistrelles. Briggler and Prather (2003) also observed that longer caves supported greater numbers, as indicated in this study by both the Student's t-test and the Spearman rank correlation. This relationship with cave length is most certainly the result of the pipistrelles' preference for hibernating in thermally stable environments (Rabinowitz, 1981; Fujita and Kunz, 1984; Briggler and Prather, 2003; Brack, 2007; Vincent and Whitaker, 2007), since the longer the cave, the greater the thermal stability (Tuttle and Stevenson, 1978; Fernández-Cortéz et al., 2006). Future studies in small caves should incorporate climate monitoring.

Internal surface area was selected as one of the morphological features to be tested not only as an alternative means of measuring cave size, but also because it has also been positively correlated with bat-species richness (Brunet and Medellín, 2001). There was no evidence from this study to support this relationship in small caves. A positive correlation with eastern pipistrelles and internal surface area is supported by Raesley and Gates (1987), who found that larger caves supported greater numbers of hibernating bats in general. This would appear to be similar to cave length, since cave volume is also known to influence cave temperature (Tuttle and Stevenson, 1978). However, an extremely significant, strong correlation was noticed between cave length and internal surface area $\left(r_{s}=0.877, P<0.001\right)$. That is, longer caves in this study had correspondingly larger internal surface areas. Therefore, these results can not say with any certainty if the preference exhibited by eastern pipistrelles was the result of cave length, internal surface area, or a combination of both interrelated spatial parameters.

The negative correlation between entrance aspect and eastern pipistrelle hibernacula would seem to indicate a preference for sinkhole entrance caves since approximately one-third of the caves in the sample $(32 \%)$ were caves with the arbitrarily assigned -90 degree aspect. Greater numbers of eastern pipistrelles were found in caves with vertical entrances. Sinkhole-entrance caves had an average of $2.13( \pm 2.23 \mathrm{SD})$ eastern pipistrelles per cave, while horizontal-entrance caves averaged $0.76( \pm 0.66 \mathrm{SD})$ per cave. Briggler and Prather (2003) found larger caves with east-facing aspects were preferred by eastern pipistrelles over other morphologies. They noted however that the majority of the east-facing caves they examined were sinkhole-entrance caves on comparatively flat ground. In this study as well, sinkhole-entrance caves were typically longer and larger, having greater internal surface area. 
The average length and internal surface area of horizontal entrance caves in this study was $15.6 \mathrm{~m}( \pm$ $8.8 \mathrm{~m} \mathrm{SD})$ and $82.3 \mathrm{~m}^{2}\left( \pm 53.1 \mathrm{~m}^{2} \mathrm{SD}\right)$, respectively. The average length and internal surface area of vertical entrance caves was $25.2 \mathrm{~m}( \pm 9.3 \mathrm{~m} \mathrm{SD})$ and $216.5 \mathrm{~m}^{2}$ $\left( \pm 128.2 \mathrm{~m}^{2} \mathrm{SD}\right)$. Briggler and Prather (2003) hypothesized that the preference they observed for sinkhole entrance caves was due to the size of the caves and not the result of entrance aspect. However, considering the previously mentioned preference for thermally stable hibernacula, this may be evidence of a preferred morphological feature when selecting a hibernaculum, since vertical entrance caves are more thermally stable than those with horizontal entrances (Daan and Wichers, 1968; Tuttle and Stevenson, 1978). This behavior has been observed in other species as well, such as the Ozark big-eared bat, which also has a preference for hibernating in caves with sinkhole entrances (Clark et al., 1996; Prather and Briggler, 2002). Like cave length and internal surface area, these results are still uncertain due to the association between entrance aspect and cave size. Based on these data, there is no way to determine if this correlation is a result of entrance aspect alone.

Despite the previously listed limitations, the results of this study and the cited works of others demonstrate that eastern pipistrelles select larger caves as hibernacula. This is supported not only by the positive Spearman rank correlations, but also by the Student's t-test that found a significant difference for caves selected by eastern pipistrelles based on cave length. This preference is most likely due to more stable temperatures present in larger caves. However, it is apparent from these data that "large" is an extremely subjective term since the largest caves in this study were only around $34 \mathrm{~m}$ in length with approximately $300 \mathrm{~m}^{2}$ of internal surface area. Based on these results, I can only conclude that even though they were small, the caves in this sample were still of sufficient size to exhibit sufficient stability of temperature that eastern pipistrelles tolerate. Although the sample size was modest and the sampling dates spread out over a twelve-year period, these results should not be discounted. Trombulak et al. (2001) used similar irregular census data spanning several decades from only twenty-three hibernacula caves to document population trends in Vermont.

This study also demonstrates that local grottos of the National Speleological Society can be a valuable source of data and play a key role in monitoring and studying local bat populations. Knowledge of hibernacula roosting habits is an indispensable tool in understanding the biogenic and anthropogenic impacts on populations (O'Shea et al., 2003; Tuttle, 2003). Accurate conservation decisions can only be made with a full understanding of hibernacula requirements (Brack, 2007), and given the threat that many species face today (e.g., white-nose syndrome, destruction of habitat, etc.), this knowledge is perhaps more important now than ever. More detailed and organized survey efforts by the Iowa Grotto, and other grottos around the country, is both encouraged and recommended.

\section{Conclusions}

Gates et al. (1984) stated that eastern pipistrelles were generalists when it came to cave selection. This is supported by Harvey (1992) and Brack et al. (2003), who noted that in the eastern United States they are known to utilize more caves as hibernacula than any other species. However, eastern pipistrelles have also been known to express a pronounced fidelity to particular hibernacula (Fujita and Kunz, 1984). In their study of underground cellars in Poland, Lesiński et al. (2004) stated that small, well-distributed hibernacula are most likely to be used by local bat communities, as this would increase their chance of survival as opposed to a long migration to a larger hibernacula site. Since hibernacula for eastern pipistrelles are presumed to be within $100 \mathrm{~km}$ of summer roosting sites (Vincent and Whitaker, 2007) and comparatively permanent roosts such as caves are able to support stable bat populations and annual use patterns (Agosta et al., 2005), it is apparent that small caves are an important source of hibernacula for the eastern pipistrelle.

Further research on the role of small caves as hibernacula is needed. First, the preferred morphology of sinkhole entrances by eastern pipistrelles evident in this study and noted by Briggler and Prather (2003) needs to be validated or refuted. At the present time, there is no way of discerning whether this is an actual preferred feature or whether this was merely a coincidental occurrence with larger caves. Second, additional data are needed in order to determine whether the presence of some species hibernating in small caves, such as the little brown bats observed in this study, are anomalies or whether these species also utilize small caves on a regular basis. Specific knowledge of hibernacula is necessary to adequately meet conservation needs (O’Shea et al., 2003; Tuttle, 2003; Brack, 2007), even for common species that are considered abundant (Agosta, 2002). A more complete understanding of roosting habitats is essential since the destruction of more significant hibernacula may result in less important sites (such as small caves) emerging as major hibernacula (Gates at al., 1984).

\section{AcKNowledgments}

I would like to thank Ed Klausner and Mike Lace for reviewing this manuscript. I would also like to thank the following fellow members of the Iowa Grotto for their diligent work in recording bat observations in Iowa caves; without them this paper would not have been possible: Ed Klausner, Elizabeth Miller, Mike Lace, Chris Beck, Gary Engh, Jim Roberts, Rich Feltes, Phil LaRue, and Ray Finn. 


\section{REFERENCES}

Agosta, S.J., 2002, Habitat use, diet and roost selection by the big brown bat (Eptesicus fuscus) in North America: A case for conserving an abundant species: Mammal Review, v. 32, p. 79-198, doi:10.1046/ j.1365-2907.2002.00103.x.

Agosta, S.J., Morton, D., Marsh, B.D., and Kuhn, K.M., 2005, Nightly, seasonal, and yearly patterns of bat activity at night roosts in the central Appalachians: Journal of Mammalogy, v. 86, p. 1210-1219, doi: 10.1644/05-MAMM-A-012R1.1.

Arita, H.T., 1996, The conservation of cave-roosting bats in Yucatan, Mexico: Biological Conservation, v. 76, p. 117-185.

Arita, H.T., and Vargas, J.A., 1995, Natural history, interspecific association, and incidence of the cave bats of Yucatan, Mexico: Southwestern Naturalist, v. 40, p. 29-37.

Best, T.L., Carey, S.D., Caesar, K.G., and Henry, T.H., 1992, Distribution and abundance of bats (Mammalia: Chiroptera) in coastal plain caves of southern Alabama: NSS Bulletin, v. 54, p. $61-65$.

Blair, A.P., 1951, Winter activity in Oklahoma frogs: Copeia, v. 2, 178 p.

Bowles, J.B., Howell, D.L., Lampe, R.P., and Whidden, H.P., 1998 , Mammals of Iowa: Holocene to the end of the 20th century: Journal of the Iowa Academy of Science, v. 105, p. 123-132.

Brack, V. Jr., Johnson, S.A., and Dunlap, R.K., 2003, Wintering populations of bats in Indiana, with emphasis on the endangered Indiana myotis, Myotis sodalis: Proceedings of the Indiana Academy of Science, v. 112, p. 61-74, (www.indianaacademyofscience.org/ media/attachments/IAS_v112_n1_p61-74.pdf).

Brack, V. Jr., 2007, Temperatures and locations used by hibernating bats, including Myotis sodalis (Indiana bat), in a limestone mine: Implications for conservation and management: Environmental Management, v. 40, p. 739-746, doi: 10.1007/s00267-006-0274-y.

Brack, V. Jr., Whitaker, J.O. Jr., and Pruitt, S.E., 2004, Bats of Hoosier National Forest: Proceedings of the Indiana Academy of Science, v. 113, p. 76-86, (www.indianaacademyofscience.org/media/attachments/ PIAS_v113_n1_p76-86.pdf).

Briggler, J.T., and Prather, J.W., 2003, Seasonal use and selection of caves by the eastern pipistrelle bat (Pipistrellus subflavus): American Midland Naturalist, v. 149, p. 406-412, doi: 10.1674/0003-0031(2003) 149[0406:SUASOC]2.0.CO;2.

Briggler, J.T., and Prather, J.W., 2006, Seasonal use and selection of caves by plethodontid salamanders in a karst area of Arkansas: American Midland Naturalist, v. 155, p. 136-148, doi: 10.1674/0003-0031(2006) 155[0136:SUASOC]2.0.CO;2.

Brunet, A.K., and Medellín, R.A., 2001, The species-area relationship in bat assemblages of tropical caves: Journal of Mammalogy, v. 82 , p. $1114-1122$, doi: $10.1644 / 1545-1542(2001) 082<1114$ :TSARIB $>$ 2.0.CO;2.

Camp, C.D., and Jensen, J.B., 2007, Use of twilight zones of caves by plethodontid salamanders: Copeia, v. 3, p. 594-604, doi: 10.1643/ 0045-8511(2007)2007[594:UOTZOC]2.0.CO;2.

Clark, B.S., Bowles, J.B., and Clark, B.K., 1987, Summer occurrences of the Indiana bat, Keen's myotis, evening bat, silver-haired bat, and eastern pipistrelle in Iowa: Proceedings of the Iowa Academy of Science, v. 94, p. 89-93.

Clark, B.K., Clark, B.S., Leslie, D.M. Jr., and Gregory, M.S., 1996, Characteristics of caves used by the endangered Ozark big-eared bat: Wildlife Society Bulletin, v. 24, p. 8-14.

Curl, R.L., 1966, Caves as a measure of karst: Journal of Geology, v. 74, p. $798-830$.

Daan, S., and Wichers, H.J., 1968, Habitat selection of bats hibernating in a limestone cave: Zeitschrift fur Saugetierkunde, v. 33, p. 262-287.

Dasher, G.R., 1994, On Station: A Complete Handbook for Surveying and Mapping Caves: Huntsville, Alabama, National Speleological Society, $242 \mathrm{p}$.

Dixon, J.W., 2009, Cave size in Iowa: How long is the average Iowa cave?: Intercom, published semi-spasmodically by the Iowa Grotto of the National Speleological Society, v. 45, p. 17-22.

Drda, W.J., 1968, A study of snakes wintering in a small cave: Journal of Herpetology, v. 1, p. 64-70.

Fernández-Cortéz, A., Calaforra, J.M., Jiménez-Espinosa, R., and Sánchez-Martos, F., 2006, Geostatistical spatiotemporal analysis of air temperature as an aid to delineating thermal stability zones in a potential show cave: Implications for environmental management:
Journal of Environmental Management, v. 81, p. 371-383, doi: 10.1016/j.jenvman.2005.11.011.

Fujita, M.S., and Kunz, T.H., 1984, Pipistrellus subflavus: Mammalian Species, v. 228, p. 1-6.

Fuszara, E., Kowalski, M., Lesiński, G., and Cygan, J.P., 1996, Hibernation of bats in underground shelters of central and northeastern Poland: Bonner zoologische Beitrage, v. 46, p. 349-358.

Gates, J.E., Feldhamer, G.A., Griffith, L.A., and Raesly, R.L., 1984, Status of cave-dwelling bats in Maryland: Importance of marginal habitats: Wildlife Society Bulletin, v. 12, p. 162-169.

Harvey, M.J., 1992, Bats of the Eastern United States: Little Rock, Arkansas, Arkansas Game and Fish Commission, 46 p.

Kambesis, P., and Lace, M., 2009, Iowa, in Palmer, A.N., and Palmer, M.V., eds., Caves and Karst of the USA: Huntsville, Alabama, National Speleological Society, p. 151-154.

Kastning, E.H., 2006, Very small eclectic caves: conservation and management issues, in Rea, G.T., ed., Proceedings of the $17^{\text {th }}$ National Cave and Karst Management Symposium: Albany, New York, NCKMS Steering Committee, p. 92-101.

Kunz, T.H., 1982, Roosting ecology of bats, in Kunz, T.H., ed., Ecology of Bats: New York, New York, Plenum Press, p. 1-55.

Kunz, T.H., and Schlitter, D.A., 1968, An annotated checklist of bats from Iowa: Transactions of the Kansas Academy of Science, v. 71, p. 166-175, (www.bu.edu/cecb/files/2009/08/iowachecklist.pdf).

Lace, M.J., ed., 1997, The Iowa Cave Map Book, Volume II: Iowa City, Iowa, Iowa Grotto of the National Speleological Society, $210 \mathrm{p}$.

Lace, M.J., and Klausner, E., eds., 2001, The Iowa Cave Map Book, Volume III: Iowa City, Iowa, Iowa Grotto of the National Speleological Society, $223 \mathrm{p}$.

Lace, M.J., and Klausner, E., eds., 2004, The Iowa Cave Map Book, Volume IV: Iowa City, Iowa, Iowa Grotto of the National Speleological Society, $183 \mathrm{p}$.

Lace, M.J., and Ohms, M., eds., 1992, The Iowa Cave Map Book, Volume I: Iowa City, Iowa, Iowa Grotto of the National Speleological Society, $151 \mathrm{p}$.

Laubach, C.M., Bowles, J.B., and Laubach, R., 1994, A Guide to the Bats of Iowa: Des Moines, Iowa, Iowa Department of Natural Resources, Nongame Technical Series No. 2, 18 p.

Lesiński, G., Kowalski, M., Domański, J., Dzięciołowski, R., LaskowskaDzięciołowska, K., and Dzięgielewska, M., 2004, The importance of small cellars to bat hibernation in Poland: Mammalia, v. 68, p. $345-352$.

Muir, T.J., and Polder, E., 1960, Notes on hibernating bats in Dubuque County caves: Proceedings of the Iowa Academy of Science, v. 67, p. 602-606.

Mylroie, J., 2007, Cave surveys, cave size, and flank margin caves: Compass \& Tape, v. 17 , no. 4, p. 8-16, (www.caves.org/section/sacs/ rr/cavelenth.pdf).

Nui, H., Wang, N., Zhao, L., and Lui, J., 2007, Distribution and underground habitats of cave-dwelling bats in China: Animal Conservation, v. 10, p. 470-477, doi: 10.1111/j.1469-1795.2007. 00136.x.

O'Shea, T.J., Bogan, M.A., and Ellison, L.E., 2003, Monitoring trends in bat populations of the United States and territories: Status of the science and recommendations for the future: Wildlife Society Bulletin, v. 31, p. 16-29, (www.fort.usgs.gov/Products/Publications/21045/ 21045.pdf).

Pierson, E.D., 1998, Tall trees, deep holes, and scarred landscapes: Conservation biology of North American bats, in Kunz, T.H., and Racey, P.A., eds., Bat Biology and Conservation: Washington, D.C., Smithsonian Institution Press, p. 309-325.

Prather, J.W., and Briggler, J.T., 2001, Use of small caves by anurans during a drought period in the Arkansas Ozarks: Journal of Herpetology, v. 35, p. 675-678.

Prather, J.W., and Briggler, J.T., 2002, Use of small caves by Ozark bigeared bats (Corynorhinus townsendii ingens) in Arkansas: American Midland Naturalist, v. 148, p. 193-197, doi: 10.1674/0003-0031(2002) 148[0193:UOSCBO]2.0.CO;2.

Pruszko, R., and Bowles, J.B., 1986, Survey of some eastern Iowa caves for wintering bats: Proceedings of the Iowa Academy of Science, v. 93, p. 41-43, (137.227.227.130/BPD/BPD_bib_viewObs.asp?BibID=1300).

Rabinowitz, A., 1981, Thermal preference of the eastern pipistrelle bat (Pipistrellus subflavus) during hibernation: Journal of the Tennessee Academy of Science, v. 56, p. 113-114. 
Raesly, R.L., and Gates, J.E., 1987, Winter habitat selection by north temperate cave bats: American Midland Naturalist, v. 118, p. $15-31$.

Rodríguez-Durán, A., 1998, Nonrandom aggregations and distributions of cave-dwelling bats in Puerto Rico: Journal of Mammalogy, v. 79, p. $141-146$.

Schwartz, C.W., and Schwartz, E.R., 2001, The Wild Mammals of Missouri: Columbia, Missouri, University of Missouri Press, 392 p.

Thomas, D.W., and LaVal, R.K., 1988, Survey and Census Methods, in Kunz, T.H., ed., Ecological and Behavioral Methods for the Study of Bats: Washington, D.C., Smithsonian Institution Press, p. 77-89.

Trombulak, S.C., Higuera, P.E., and DesMeules, M., 2001, Population trends of wintering bats in Vermont: Northeastern Naturalist, v. 8, p. 51-62, doi: 10.1656/1092-6194(2001)008[0051:PTOWBI]2.0.CO;2.

Tuttle, M.D., 2003, Estimating population sizes of hibernating bats in caves and mines, in O'Shea, T.J., and Bogan, M.A., eds., Monitoring Trends in Bat Populations of the United States and Territories:
Problems and Prospects: U.S. Geological Survey, Biological Resources Discipline, Information and Technology Report USGS/BRD/ITR2003-0003. p. 31-39.

Tuttle, M.D., and Stevenson, D.E., 1978, Variation in the cave environment and its biological implications, in Zuber, R., Chester, J., Gilbert, S., and Rhodes, D., eds., Proceedings of the 1977 National Cave Management Symposium: Albuquerque, New Mexico, Adobe Press, p. 108-121.

Vincent, E.A., and Whitaker, J.O. Jr., 2007, Hibernation of the eastern pipistrelle, Perimyotis subflavus, in an abandoned mine in Vermillion County, Indiana, with some information on Myotis lucifugus: Proceedings of the Indiana Academy of Science, v. 116, p. 58-65, (www.indianaacademyofscience.org/media/attachments/Proc_v116_ 1_2007_pp58-65.pdf)

Whitaker, J.O. Jr., and Rissler, L.J., 1992, Seasonal activity of bats at Copperhead Cave: Proceedings the Indiana Academy of Science, v. 101 , p. $127-134$. 